\title{
Integrin- $\alpha_{5}$ Mediates Epidermal Growth Factor-Induced Retinal Pigment Epithelial Cell Proliferation and Migration
}

\author{
Zhen Chen ${ }^{a}$ Chang-zheng Chen ${ }^{a}$ Wen-rong Gong ${ }^{b}$ Jun-ping Lic, d \\ Yi-qiao Xing ${ }^{\text {a }}$ \\ a Department of Ophthalmology, and ${ }^{b}$ Central Laboratory, Renmin Hospital, Wuhan University, Wuhan, China; \\ 'Department of Ophthalmology, VA Medical Center, Salem, Mass., and d Department of Ophthalmology, \\ University of Virginia, Charlottesville, Va., USA
}

\section{Key Words}

Epidermal growth factor $\cdot$ Retinal pigment epithelial cells • Integrin- $\alpha_{5} \cdot$ Proliferation $\cdot$ Migration

\begin{abstract}
Proliferation and migration of retinal pigment epithelial (RPE) cells play a crucial role in proliferative vitreoretinopathy (PVR)-related pathology. Cytokines, including EGF, can result in RPE cell activation and cause PVR. In this study, integrin- $\alpha_{5}$ expression was first studied in PVR membranes by immunofluorescence. Then the effect of EGF on integrin- $\alpha_{5}$ expression was determined by flow cytometry, Western blot analysis and the reverse-transcription polymerase chain reaction (RT-PCR) in the ARPE-19 cell line. Proliferation and migration of ARPE-19 cells were measured by the methylthiazolyldiphenyl-tetrazolium bromide and Boyden chamber assays. We found that a higher level integrin- $\alpha_{5}$ was present at the RPE cell surface in PVR compared with normal retina. EGF could dose dependently increase integrin- $\alpha_{5}$ mRNA and protein levels in vitro. EGF promoted ARPE-19 cell proliferation and migration. Neutralizing integrin- $\alpha_{5}$ by specific antiintegrin- $\alpha_{5}$ antibody abolished most of the effects of EGF. The study provided evidence that EGF might influence PVR by promoting integrin- $\alpha_{5}$ expression and subsequent proliferation and migration of RPE.

Copyright ๑ 2010 S. Karger AG, Base
\end{abstract}

\section{Introduction}

Proliferative vitreoretinopathy (PVR) is a serious complication of major ocular trauma and rhegmatogenous retinal detachment. Retinal pigment epithelial (RPE) cells are the predominant and critical cell type in PVR membranes [1]. Studies on cultured RPE cells have shown that they attach to and spread on individual matrix molecules, such as collagen [2], laminin [3, 4] and fibronectin (FN) [5]. In early stages of PVR, the provisional extracellular matrix $(\mathrm{ECM})$ is synthesized locally by several cell types including RPE cells [6]. RPE cells interact with the ECM, migrate and proliferate.

Integrins mediate interactions between cells and the ECM $[7,8]$. Changes in integrin expression have been shown in a variety of proliferative disorders including cancer [9], wound healing [10], and angiogenesis [11]. Integrins are heterodimers consisting of variable $\alpha$ - and $\beta$ subunits. The different combinations of these subunits determine the receptor specificity [12]. The $\alpha_{5} \beta_{1}$-integrin mediates specific binding to FN [13] in a number of cell types, including leukemic cells [14], mammary carcinoma cells [15], aortic endothelial cells [16], fibroblasts [17], and RPE cells [18]. Cell spreading and proliferation are inhibited in $\alpha_{5}$-deficient normal rat kidney fibroblasts [19]. Mammary carcinoma cell proliferation is inhibited by antibodies to $\alpha_{5} \beta_{1}[15]$.

\section{KARGER}

Fax +4161306 1234 E-Mail karger@karger.ch www.karger.com
Yi-qiao Xing and Weng-rong Gong

Department of Ophthalmology and Central Laboratory

Renmin Hospital, Wuhan University

Wuchang Jiefang Road 238, Wuhan 430060 (China)

Tel. +86 278804 1911, ext. 82061, Fax +86 278805 7872, E-Mail xyqdr07@yahoo.com.cn 
Table 1. Clinical characteristics of PVR membranes

\begin{tabular}{rllll}
\hline Patient No. & Age, years & Sex & Diagnosis & Associated condition \\
\hline 1 & 39 & M & PVR epiretinal membrane & $\begin{array}{l}\text { retinal detachment after ocular trauma } \\
\text { retinal detachment, huge hole }\end{array}$ \\
2 & 45 & M & PVR epiretinal membrane & $\begin{array}{l}\text { rhegmatogenous retinal detachment } \\
3\end{array}$ \\
4 & 43 & M & PVR epiretinal membrane & retinal detachment after ocular trauma \\
5 & 61 & M & PVR epiretinal membrane & rhegmatogenous retinal detachment \\
6 & 41 & F & PVR epiretinal membrane & retinal detachment, huge hole \\
7 & 60 & M & PVR epiretinal membrane & rhegmatogenous retinal detachment \\
8 & 55 & F & PVR epiretinal membrane & rhegrinal detachment after ocular trauma \\
9 & 31 & F & PVR subretinal membrane & retinatachent \\
10 & 33 & M & PVR subretinal membrane & recurrent retinal detachment \\
11 & 51 & M & PVR epiretinal membrane & recurrent retinal detachment \\
12 & 50 & M & PVR subretinal membrane & recurrent retinal detachment \\
13 & 48 & F & PVR epiretinal membrane & retinal detachment after ocular trauma \\
14 & 60 & F & PVR epiretinal membrane & recurrent retinal detachment \\
& 41 & M & PVR subretinal membrane & rhegmatogenous retinal detachment \\
\hline
\end{tabular}

Regulation of integrin expression is strongly influenced by cytokines, including those that are present in PVR membranes [20]. Endothelial growth factor (EGF) has been found in the vitreous, subretinal fluid and PVR membranes in PVR patients [21]. In a previous study, EGF was shown to promote RPE cell proliferation in vitro [22]. All these findings indicate that EGF may play an important role in PVR formation. However, the molecular basis for EGF effects in PVR membranes remains to be determined.

In this study, we first examined the expression of integrin- $\alpha_{5}$ in PVR membranes and normal retina. Then, the effects of EGF on the expression of integrin- $\alpha_{5}$, cell proliferation and migration were investigated in cultured RPE cells.

\section{Materials and Methods}

\section{Immunofluorescence Staining of Human PVR and Control}

Retina Samples

Retina samples from 14 patients with PVR were collected from January to September of 2008 in the Department of Ophthalmology, Renmin Hospital, Wuhan University. Among them, 9 cases were males ( 9 eyes), 5 cases were females ( 5 eyes). The average age was 47 years. Clinical histories are given in table 1 . Six retina specimens were obtained from the normal eyes of cornea transplant donors and served as controls. None of the donors had a known history of eye disease. Among them, 4 cases were males (4 eyes), 2 cases were females ( 2 eyes). Age range: $28-51$ years, mean $=40$ years. This research was conducted in accordance with the tenets of the Declaration of Helsinki, and was approved by the Ethics Committee of the Wuhan University School of Medicine. In- formed consent was obtained from all subjects before the research. The specimens were fixed with $4 \%$ paraformaldehyde in PBS for $24 \mathrm{~h}$ at $4^{\circ} \mathrm{C}$. Following incubation in $20 \%$ sucrose for $2 \mathrm{~h}$ at room temperature and $30 \%$ sucrose for $24 \mathrm{~h}$ at $4^{\circ} \mathrm{C}$, the specimens were embedded at the optimal cutting temperature in a compound containing 3\% glycerol and frozen in liquid nitrogen. Sections of $4-6 \mu \mathrm{m}$ were cut and stored at $-86^{\circ} \mathrm{C}$ pending use. For staining, sections were first incubated for $20 \mathrm{~min}$ at room temperature in $95 \%$ ethanol, and then treated with $0.25 \%$ potassium permanganate for $15 \mathrm{~min}$ at room temperature to reduce autofluorescence arising from lipofuscin present in the RPE cells. Sections were blocked overnight at $4^{\circ} \mathrm{C}$ in $5 \%$ goat serum (Pierce, USA), then incubated for $90 \mathrm{~min}$ at $37^{\circ} \mathrm{C}$ with mouse anti-integrin- $\alpha_{5}$ monoclonal antibody (Chemicon, USA), or with normal mouse serum (Sigma) as negative controls, both at 1:100 dilution. Sections were washed and blocked again in 5\% goat serum for 60 min at $37^{\circ} \mathrm{C}$, and incubated with secondary antibody (anti-mouse IgG-labeled with FITC, Pierce) at 1:100 dilution for $90 \mathrm{~min}$ at $37^{\circ} \mathrm{C}$. Sections were subjected to sequential excitation with the 488-nm line and examined with a fluorescent microscope (BX60, Olympus, Japan).

\section{Cell Culture}

Human RPE cells, ARPE-19 cell line, were purchased from American Type Culture Collection (ATCC, USA). The cells were cultured in Dulbecco's Modified Eagle Medium/Nutrient Mixture F-12 (DMEM/F12) (Gibco, USA) with 10\% fetal bovine serum (FBS, Gibco). The medium was changed every 3-4 days and cultures were maintained in an incubator at $37^{\circ} \mathrm{C}$ in $5 \% \mathrm{CO}_{2} / 95 \%$ air atmosphere.

\section{Total RNA Isolation and Reverse-Transcription Polymerase}

Chain Reaction

For testing the effects of EGF, $2 \times 10^{5}$ ARPE-19 cells were incubated in 6-well plates. Cells were first cultured in DMEM/F12 with $0.1 \%$ FBS for $48 \mathrm{~h}$. Then the medium was removed and cells were washed three times with PBS, cultured again in DMEM/F12 
without serum. At that time point, the EGF (Cytolab, USA, dissolved in DMEM/F12) was administered. The final concentrations of EGF in the wells were $0,0.1,1,10,20$ and $100 \mathrm{ng} / \mathrm{ml}$, respectively.

Tri-Reagent (Sigma) was used to extract total cellular RNA at 12,24 and $48 \mathrm{~h}$ according to the manufacturer's instructions. One microgram of total RNA was used in the synthesis of first-strand complementary DNA (cDNA) with avian myoblastoma virus reverse transcriptase and oligo(dT) primers using standard protocols. The reverse-transcription polymerase chain reaction (RTPCR) for integrin- $\alpha_{5}$ was carried out at $94^{\circ} \mathrm{C}$ for $30 \mathrm{~s}$, at $60^{\circ} \mathrm{C}$ for $30 \mathrm{~s}$ and finally at $72^{\circ} \mathrm{C}$ for $30 \mathrm{~s}$ in a total of 30 cycles. Reagent boxes (Boshide, China) were used in RT-PCR. In order to assess the level of integrin $-\alpha_{5}$ expression semi-quantitatively, $\beta$-actin was coamplified as the internal reference. The primers used for intergrin- $\alpha_{5}$ were: forward 5'-GGCAGCTATGGCGTCCCACTGTGG-3', reverse 5'-GGCATCAGAGGTGGCTGGAGGCTT-3' (171-bp PCR product). The primers used for $\beta$-actin were: forward 5'-TGGATGACGATATCGCTGCTCG-3', reverse 5'-GGTGCTCCTCAGGGGCCACACG-3' (456-bp PCR product). Bands were analyzed with the GelDoc2000 gel documentation system and the QuantityOne 1-D image analysis software (Bio-Rad Laboratories). The ratio of integrin- $\alpha_{5}$ mRNA to $\beta$-actin mRNA was calculated.

\section{Western Blot Analysis of Integrin- $\alpha_{5}$ Protein Expression}

After 24 h of culture as described above, the ARPE-19 cells were washed twice in PBS, lysed in $200 \mu$ l of ice-cold lysis buffer containing $150 \mathrm{~mm} \mathrm{NaCl}, 2 \%$ SDS, $5 \mathrm{~mm}$ EDTA, and $20 \mathrm{~mm}$ Tris-HCl $(\mathrm{pH} 7.5)$ and centrifuged at $4^{\circ} \mathrm{C}$ for $10 \mathrm{~min}$ at $10,000 \mathrm{~g}$. Cell lysates were mixed with sample buffer and heated for $5 \mathrm{~min}$ at $95^{\circ} \mathrm{C}$. They were then resolved by SDS-PAGE, transferred to nitrocellulose filters by electroblot, and probed with monoclonal antibodies (diluted 1:500, mouse anti-human integrin- $\alpha_{5}$ monoclonal antibodies, Chemicon) directed against integrin- $\alpha_{5}$. The primary antibody was detected with a horseradish peroxidase-conjugated goat anti-mouse secondary antibody. Enhanced chemiluminescence substrate was used to detect the secondary antibody according to the manufacturer's instructions, and the membrane was placed against autoradiographic film (Hyperfilm ECL; Amersham, France). Monoclonal antibody directed against GAPDH was used as an internal standard for checking protein loading.

Flow Cytometry Analysis of Integrin- $\alpha_{5}$ Protein Expression

The ARPE-19 cells were harvested and suspended in PBS, and cell density was adjusted to $5 \times 10^{6} / \mathrm{ml}$. Two hundred microliters of cell suspension were transferred to a $5-\mathrm{ml}$ sterile tube. The cells were cultured with $5 \%$ goat serum for $10 \mathrm{~min}$ at room temperature. Then the first antibody (diluted 1:100) was added and the cells were incubated for $1 \mathrm{~h}$ at $4^{\circ} \mathrm{C}$ followed by washing with PBS. Normal mouse serum (diluted 1:100, Sigma) was used for negative controls. The second antibody (anti-mouse IgG FITC conjugate, diluted 1:50, Pierce) was added and cells were incubated under the same conditions for $1 \mathrm{~h}$; incubation was followed by washing with PBS. The cells were fixed for $10 \mathrm{~min}$ with $1 \%$ paraformaldehyde and observed by flow cytometry (Elite Esp FACScan, Beckman Coulter, USA). 5,000 cells were tested for each of the groups. The data were obtained and analyzed by using FCSExpress 3.0 software. The difference of integrin- $\alpha_{5}$ expression was analyzed according to the average cell fluorescence intensity.
ARPE-19 Cell Proliferation Experiment

(Methylthiazolyldiphenyl-Tetrazolium Bromide Assay)

ARPE-19 cells were inoculated in 96-well plates at the density of $5 \times 10^{4} / \mathrm{ml} ; 200 \mu \mathrm{l}$ cell suspension was applied to each well. The cells were cultured in DMEM/F12 medium with $0.1 \%$ FBS for $48 \mathrm{~h}$. After removing the medium, the cells were washed with PBS three times. Then cells were divided into 4 groups. Empty control group: DMEM/F12 alone; EGF group: DMEM/F12 + $10 \mathrm{ng} / \mathrm{ml}$ EGF; $\alpha_{5}$-antibody group: DMEM/F12 + $10 \mathrm{ng} / \mathrm{ml} \mathrm{EGF} \mathrm{+} \mathrm{mouse}$ anti-human integrin- $\alpha_{5}$ monoclonal antibody (1:100); irrelevantantibody group: DMEM/F12 + $10 \mathrm{ng} / \mathrm{ml} \mathrm{EGF} \mathrm{+} \mathrm{irrelevant} \mathrm{anti-}$ body (mouse anti-human vimentin monoclonal antibody, 1:100, Chemicon). After $24 \mathrm{~h}$ culture as indicated for each group, cells were incubated for another $4 \mathrm{~h}$ after adding $20 \mu \mathrm{l} /$ well methylthiazolyldiphenyl-tetrazolium bromide (MTT, Sigma). Following removal of the supernatant, $150 \mu$ l dimethylsulfoxide (Sigma) was added into each well and the plate was oscillated for $15 \mathrm{~min}$. Aperture stop absorption (optical density, OD) was measured colorimetrically at $490 \mathrm{~nm}$ (EL-800, Biotek, USA).

\section{ARPE-19 Cell Migration Experiment (Boyden Chamber)}

The migration of ARPE-19 cells was detected in a Boyden chamber (Millipore, USA). The experimental groups were the same as in the cell proliferation experiment. Cells were harvested by trypsinization. In the cell suspension, cell density was adjusted to $1 \times 10^{6} / \mathrm{ml}$ with DMEM/F12. DMEM/F12 with $10 \% \mathrm{FBS}$ was added into the lower chamber of the Boyden chamber, and then covered with $8-\mu \mathrm{m}$ polycarbonate micropore membrane. $800 \mu \mathrm{l}$ of cell suspension were added into the upper Boyden chamber and conventionally cultured for $5 \mathrm{~h}$. After $5 \mathrm{~h}$ of culture, cells on the upper side of the polycarbonate membrane were wiped off with cotton; the cells on the lower side of the polycarbonate membrane were fixed in formalin and then stained with Giemsa. The 5 random fields of the polycarbonate membrane were observed under a $400 \times$ magnification optical microscope and cells were counted. These cells represented the cells with increased migration ability.

\section{Statistical Analysis}

All experiments were repeated three times. Statistical analysis software SPSS11.5 was used. Values are means \pm SEM. One-way ANOVA was used to analyze the overall data of every group, and the least significant difference (LSD) $t$ test was used to analyze multicomparison of every group at the same time. The level of confidence for statistical significance was determined to be $\mathrm{p}<$ 0.05 .

\section{Results}

\section{Integrin- $\alpha_{5}$ Expression Was Increased in Human PVR Membranes}

We used an immunofluorescence assay to investigate the expression of integrin- $\alpha_{5}$ in PVR membranes and normal retina. The expression of integrin- $\alpha_{5}$ was detected (green fluorescent signal) in all 14 samples of PVR membrane and in 6 samples of normal retina. However, 
Fig. 1. Immunofluorescence of integrin- $\alpha_{5}$ in PVR membranes and normal retina. a Light-microscopic structure of a PVR membrane. HE. $\times 100$. b Mouse anti-integrin- $\alpha_{5}$ monoclonal antibody in a PVR membrane showing strong fluorescence signal (arrows). c Negative control in a PVR membrane: normal mouse serum immunofluorescence does not show any specific signal. d Light-microscopic structure of normal retina. Mono cell layer of RPE (arrows). GLC = Ganglion cell layer; $\mathrm{INL}=$ inner nuclear layer; $\mathrm{ONL}=$ outer nuclear layer. HE. × 200. e Mouse antiintegrin- $\alpha_{5}$ monoclonal antibody in normal retina emitting a weak fluorescence signal on the surface of the neighboring Bruch's membrane. f Negative control for normal retina: normal mouse serum does not show any specific signal. Scale bar: 10 $\mu \mathrm{m}$.
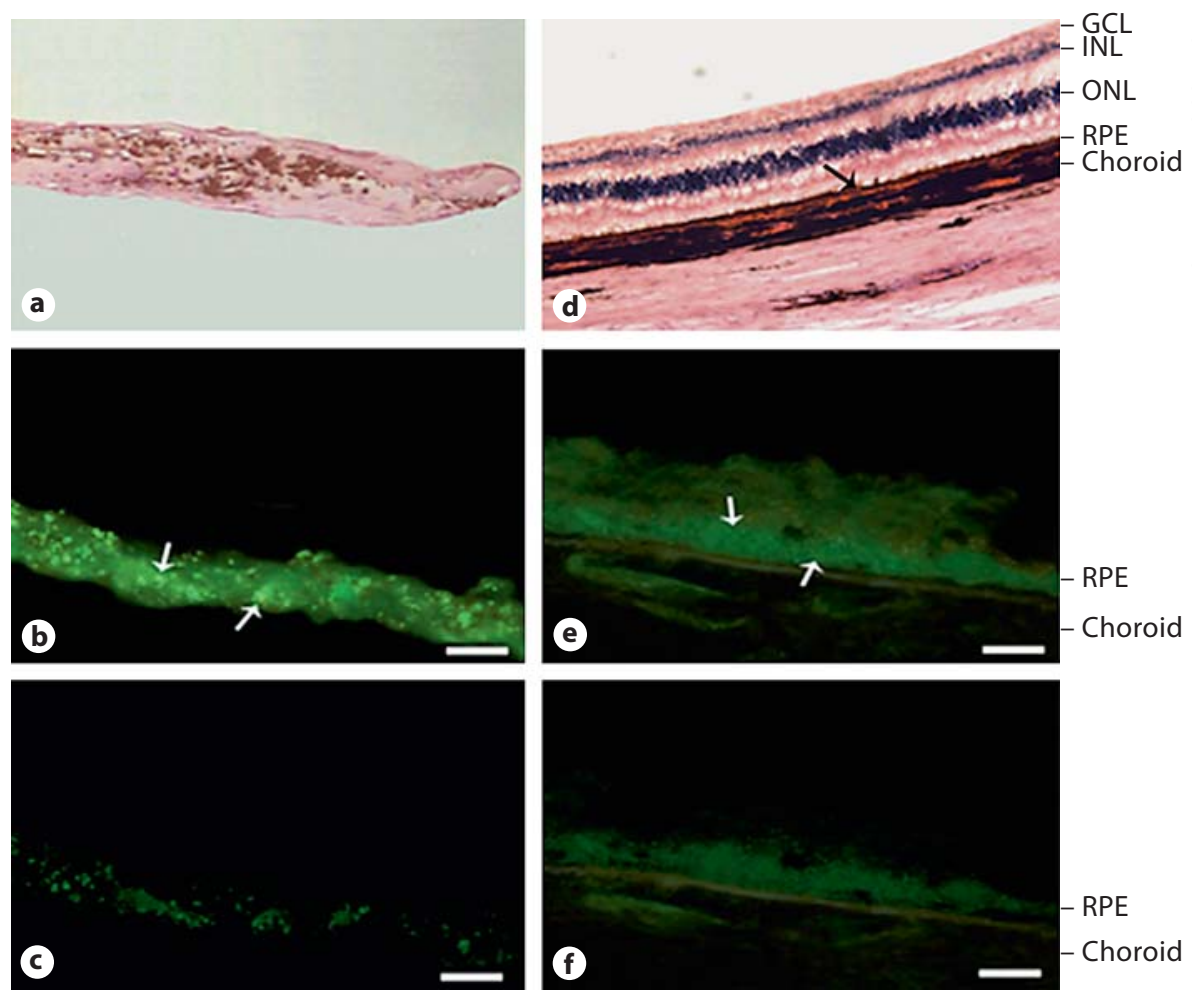

RPE

Choroid

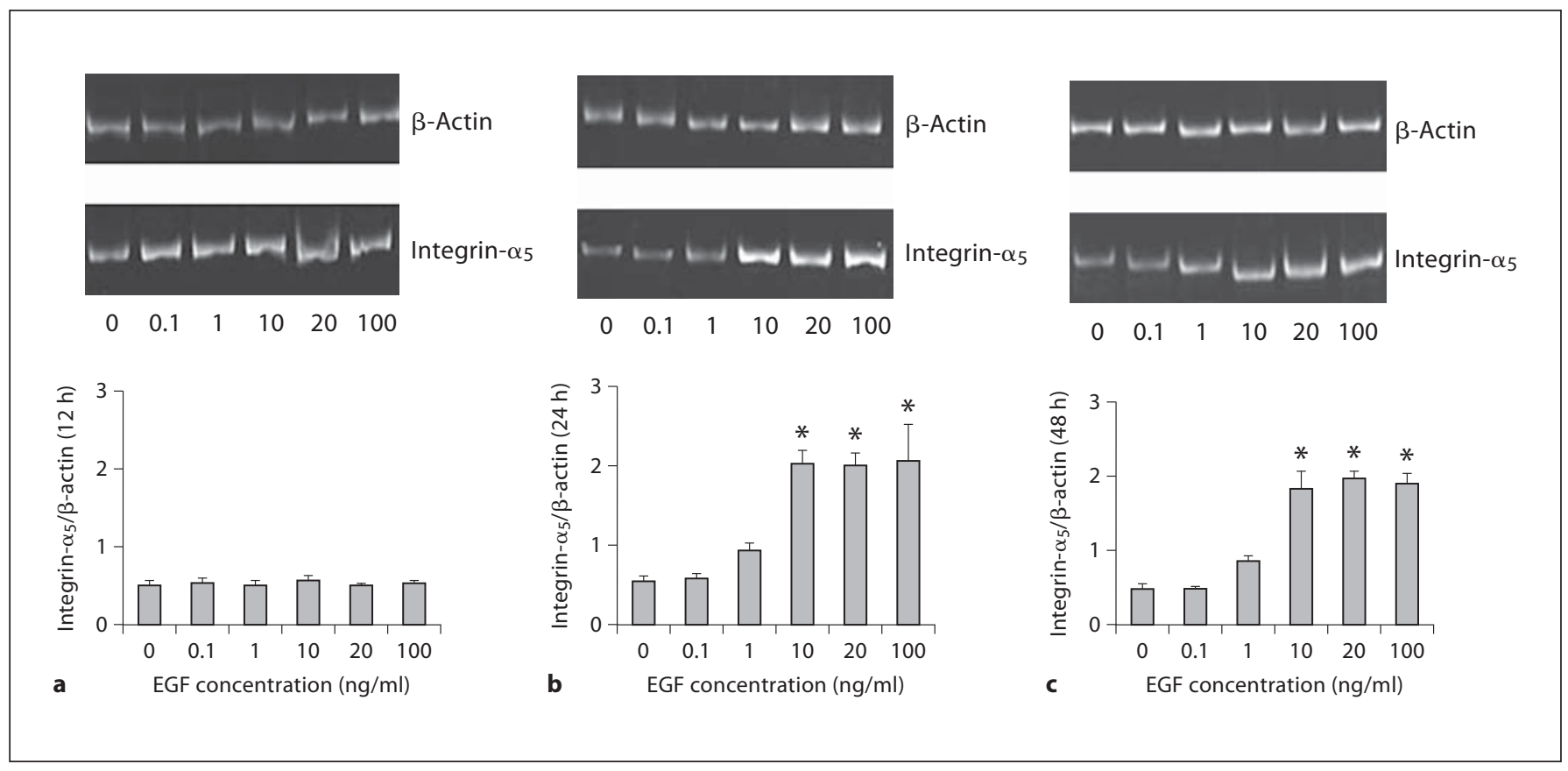

Fig. 2. Effect of EGF on integrin- $\alpha_{5}$ mRNA expression in ARPE19 cells. Semiquantitative PCR: $\beta$-actin mRNA was coamplified as internal control and the ratios between integrin- $\alpha_{5}$ mRNA and $\beta$-actin mRNA were compared. a No effect of EGF is detected af- ter $12 \mathrm{~h}$. b, c After $24 \mathrm{~h}$ and $48 \mathrm{~h}$, increased integrin- $\alpha_{5}$ mRNA is observed with increasing EGF concentrations; the effect peaks at $10-100 \mathrm{ng} / \mathrm{ml} \mathrm{EGF}$ concentration $\left({ }^{*} \mathrm{p}<0.01\right.$ vs. $0,0.1$ and $1 \mathrm{ng} / \mathrm{ml}$ concentration EGF groups). 


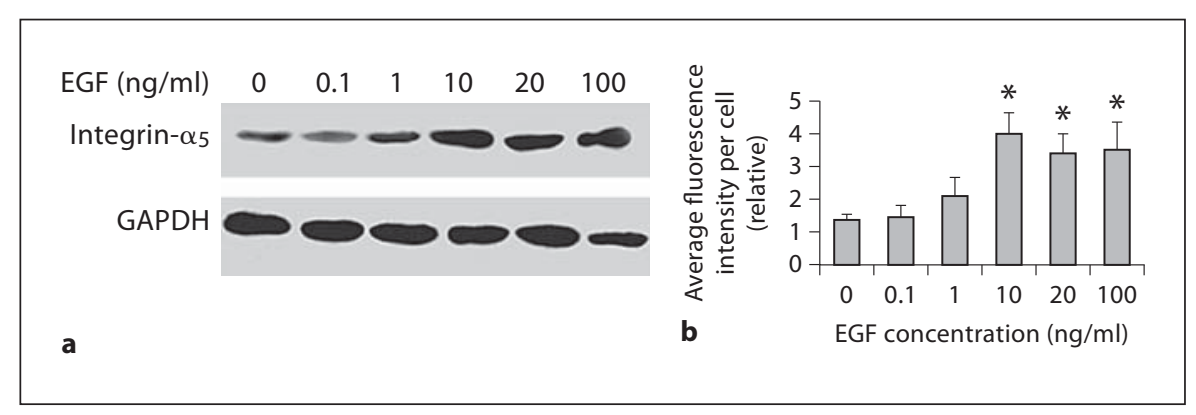

Fig. 3. Integrin- $\alpha_{5}$ protein expression induced by EGF. a Representative Western blots for integrin- $\alpha_{5}$ and GADPH protein in ARPE-19 cells treated with different concentrations of EGF in $24 \mathrm{~h}$. EGF induced integrin- $\alpha_{5}$ protein expression from 1 to 100 $\mathrm{ng} / \mathrm{ml}$. The peak effect appears at concentrations ranging from
10 to $100 \mathrm{ng} / \mathrm{ml}$. b Integrin- $\alpha_{5}$ protein expression induced by different concentrations of EGF was determined by flow cytometry. Integrin- $\alpha_{5}$ expression is dramatically increased in the groups treated at concentrations ranging from 10 to $100 \mathrm{ng} / \mathrm{ml} \mathrm{EGF}$ in $24 \mathrm{~h}\left({ }^{*} \mathrm{p}<0.01\right.$ vs. $0,0.1$ and $\left.1 \mathrm{ng} / \mathrm{ml} \mathrm{EGF}\right)$. the staining for integrin- $\alpha_{5}$ was strongly positive on the surface of RPE cells in the full thickness of the PVR membrane (fig. 1b). The expression of integrin- $\alpha_{5}$ was only evident in the RPE monolayer in control samples, in which the staining was primarily concentrated along the basal surface of the cells neighboring Bruch's membrane with weak green fluorescence signals (fig. 1d).

\section{EGF Increased Integrin- $\alpha_{5} m R N A$ and Protein \\ Expression in Cultured ARPE-19 Cells}

Since we demonstrated increased expression of integrin- $\alpha_{5}$ in the presumed RPE cells in PVR membrane in vivo, we next tried to determine whether EGF induces integrin- $\alpha_{5}$ expression in RPE cell in vitro. Cultured ARPE-19 cells were treated with EGF and then integrin$\alpha_{5}$ mRNA expression was determined semiquantitatively by using RT-PCR. $\beta$-Actin mRNA was coamplified as the internal control and the ratio between integrin- $\alpha_{5}$ mRNA and $\beta$-actin mRNA was compared. After $12 \mathrm{~h}$, there was no significant effect of EGF on the expression of integrin$\alpha_{5}$ mRNA in ARPE-19 cells (fig. 2a). However, increased expression of integrin- $\alpha_{5}$ mRNA was detected after stimulation with EGF for 24 and 48 h (fig. 2b, c). After 24 h, the effect of EGF on integrin- $\alpha_{5}$ mRNA expression started at $1 \mathrm{ng} / \mathrm{ml}$ of EGF $(0.94 \pm 0.08)$ and peaked at 10,20 and $100 \mathrm{ng} / \mathrm{ml}(2.04 \pm 0.15,1.99 \pm 0.17,2.05 \pm 0.48)$ $(\mathrm{p}<0.01)$. Compared with the control group $(0.56 \pm$ $0.05)$, there was no significant effect with $0.1 \mathrm{ng} / \mathrm{ml}$ of $\operatorname{EGF}(0.58 \pm 0.06)(\mathrm{p}>0.05)$.

Consistent with the expression of integrin- $\alpha_{5}$ mRNA described above, the integrin- $\alpha_{5}$ protein level in ARPE19 cells was also significantly enhanced by EGF treatment for $24 \mathrm{~h}$ as evidenced by Western blot analysis (fig. 3a) and flow cy tometry (fig. 3b). In flow cy tometry, stronger fluorescence intensity of integrin- $\alpha_{5}$ was observed in groups treated with $10 \mathrm{ng} / \mathrm{ml}(3.98 \pm 0.67), 20 \mathrm{ng} / \mathrm{ml}$ $(3.37 \pm 0.63)$ and $100 \mathrm{ng} / \mathrm{ml}(3.53 \pm 0.79)$ of EGF, compared with the control $(1.34 \pm 0.22)$ and the group treated with $0.1 \mathrm{ng} / \mathrm{ml}(1.41 \pm 0.37)$; the differences were statistically significant $(\mathrm{p}<0.01)$.

EGF-Induced Proliferation and Migration of ARPE-19 Cells Was Largely Abolished by Addition of Antibody

to Integrin- $\alpha_{5}$

EGF increased the proliferation of ARPE-19 cells. Compared with the control group (0.297 \pm 0.024$)$, significant proliferation of ARPE-19 cells was found in the EGF group $(0.508 \pm 0.084)(\mathrm{p}<0.01)$. The use of mouse anti-human integrin- $\alpha_{5}$ monoclonal antibody to neutralize integrin- $\alpha_{5}$ abolished most of the EGF effects on cell proliferation $(\mathrm{p}<0.01)$. However, there was still a statistically significant difference between the $\alpha_{5}$-antibody group $(0.380 \pm 0.056)$ and the control group $(\mathrm{p}<0.05)$. In the irrelevant-antibody control group $(0.486 \pm 0.051)$, the effect of EGF on cell proliferation remained (fig. 4a).

The effects of EGF on migration of ARPE-19 cells were tested by the Boyden chamber assay (fig. $4 \mathrm{~b}, \mathrm{c}$ ). When the cells were stimulated with EGF, the number of migration cells was increased in the EGF $(25.6 \pm 3.8)$ and irrelevantantibody (24.4 \pm 4.1$)$ groups. Compared with these two groups, the number of migration cells was significantly lower in the control $(5.7 \pm 1.4)$ and $\alpha_{5}$-antibody (13.4 \pm 2.7) groups $(\mathrm{p}<0.01)$. Migrated cells were decreased by integrin- $\alpha_{5}$ antibody $(\mathrm{p}<0.01)$. However, there was still a statistically significant difference between the control and the $\alpha_{5}$-antibody groups $(\mathrm{p}<0.05)$. 


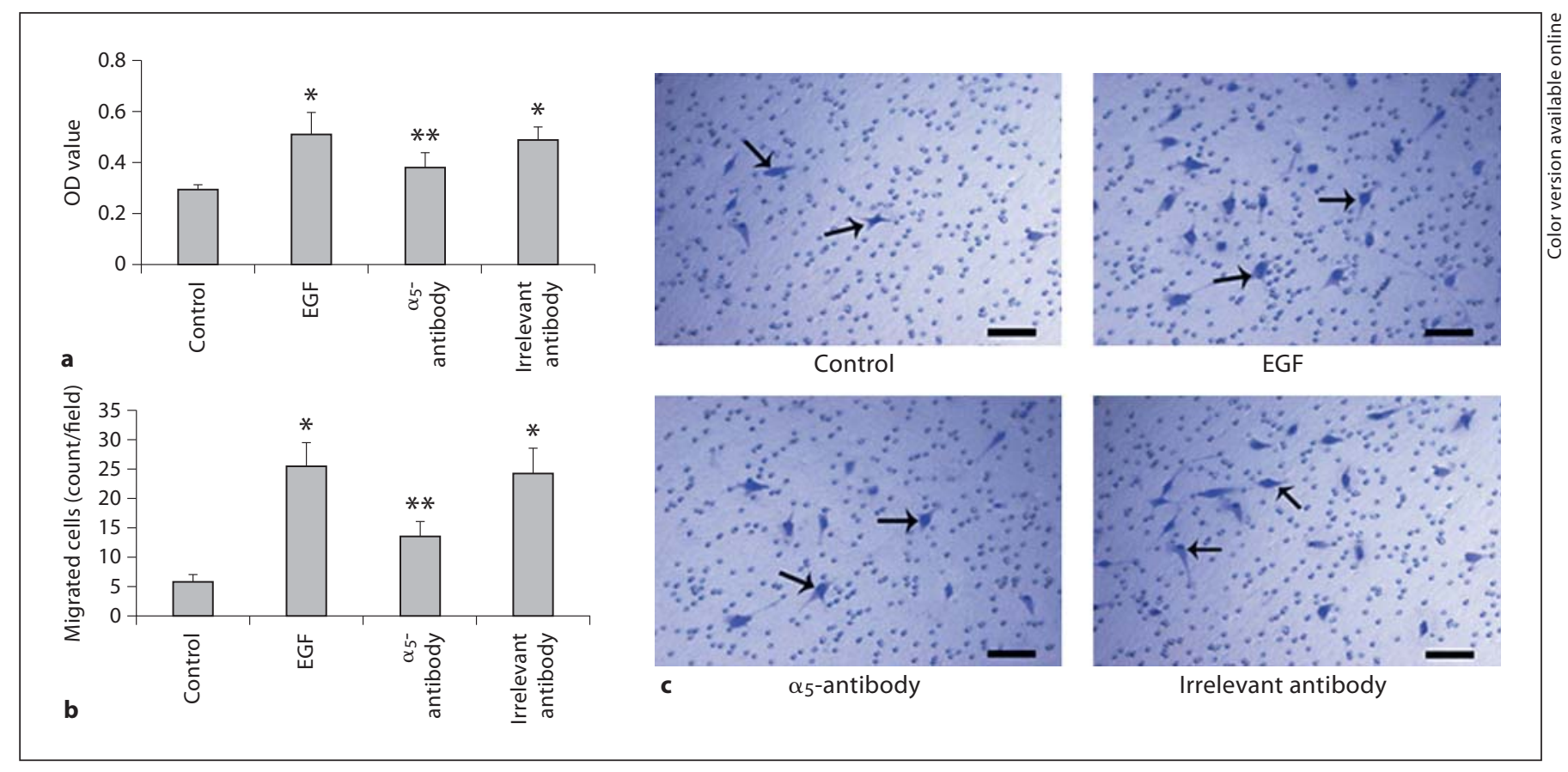

Fig. 4. Effects of EGF on ARPE-19 cell proliferation and migration. a, b Compared with controls, EGF promotes ARPE-19 cell proliferation and migration $\left({ }^{*} \mathrm{p}<0.01\right)$. When integrin $\alpha_{5}$ is blocked by neutralizing antibody, most effects are abolished $\left({ }^{*} \mathrm{p}<0.01\right)$. Irrelevant antibody does not influence these ef- fects. However, there remains a statistically significant difference between the $\alpha_{5}$-antibody group and the control group ${ }^{* *} \mathrm{p}<$ 0.05). c Result of Boyden chamber assay: the migrated ARPE-19 cells are stained blue (arrow). Scale bar: $100 \mu \mathrm{m}$.

\section{Discussion}

Previous studies $[23,24]$ demonstrated a lack of integrin- $\alpha_{5}$ expression on the RPE cell surface of human and chicken normal retinal tissue. But recent work revealed that there was some integrin- $\alpha_{5}$ expression on the normal retina RPE cell surface [25]. Robbins et al. [26] showed positive integrin- $\alpha_{5}$ expression on RPE in PVR. FN, a special ligand of integrin- $\alpha_{5}$, was also found in PVR [27]. These findings suggested that integrin- $\alpha_{5} / \mathrm{FN}$ may be involved in the formation of PVR [28]. Our results in the normal retina showed the existence of integrin- $\alpha_{5}$ on the RPE cell surfaces of normal retinae confining to the vicinity of Bruch's membrane surface. The expression of integrin- $\alpha_{5}$ was relatively weak in normal retinal tissue, but strong in PVR membranes. This suggested that integrin- $\alpha_{5}$ might play an important role in this condition.

The severity of PVR is closely associated with the role of growth factors [29]. EGF is secreted by epithelial cells. Intracellular tyrosine is activated by the binding of EGF receptor with its ligand - EGF [30]. In vitro, EGF pro- motes adhesion and migration of human cutaneous squamous carcinoma cells and keratinocytes by inducing the expression of integrin- $\alpha_{2}[31,32]$. In this study, we demonstrated that EGF induced integrin- $\alpha_{5}$ expression at both mRNA and protein levels in the ARPE-19 cells. The most effective concentration was $10 \mathrm{ng} / \mathrm{ml}$; a further increase in concentration had no additional effects.

RPE cells proliferate and form contraction membranes on both surfaces of the neural retina. It is an important pathology of the PVR $[33,34]$. In the pathological condition of rhegmatogenous retinal detachment, RPE cells migrate and form multi-layered cells. This is the primary and key process in the development of PVR. Integrin signaling results in actin cytoskeleton polymerization, which in turn regulates cell shape and motility [35]. Without migration, RPE cells will not gain access to the vitreous. It was shown previously that monoclonal antibody inhibition of integrin- $\beta_{1}$ or $-\alpha_{1}$ inhibited RPE cell migration $[12,18]$. Our study further demonstrated that in the case of EGF-induced ARPE-19 cell proliferation and migration, integrin- $\alpha_{5}$ mediated this process. Neutralizing integrin- $\alpha_{5}$ by specific antibody could 
abolish most of the effects of EGF on cell proliferation and migration. Identification of the role of integrin- $\alpha_{5}$ may help to develop selective methods for the inhibition of PVR.

Compared with the integrin- $\alpha_{5}$ antibody group, EGF effects on cell proliferation and migration were still visible in the irrelevant-antibody group. This indicates that integrin- $\alpha_{5}$ expression was not the sole reason why EGF could cause cell proliferation and migration. Further studies are needed to determine the other pathways through which EGF exerts its effect on the proliferation and migration of the ARPE-19 cells.

\section{Conclusion}

Our results indicate that EGF may induce RPE cell proliferation and migration by promoting integrin- $\alpha_{5}$ signaling. Medications aimed at blocking this molecule could be a useful adjunct pharmacological therapy in the prevention of PVR.

\section{Acknowledgment}

This project was supported by a fellowship to Z.C., Renmin Hospital, Wuhan University.

\section{References}

1 Charteris DG: Proliferative vitreoretinopathy: pathobiology, surgical management, and adjunctive treatment. Br J Ophthalmol 1995; 79:953-960.

-2 Hoffmann S, He S, Jin M, Ehren M, Wiedemann P, Ryan SJ, Hinton DR: A selective cyclic integrin antagonist blocks the integrin receptors $\alpha_{\mathrm{v}} \beta_{3}$ and $\alpha_{\mathrm{v}} \beta_{5}$ and inhibits retinal pigment epithelium cell attachment, migration and invasion. BMC Ophthalmol 2005;5: 16.

3 Campochiaro PA, Hackett SF: Corneal endothelial cell matrix promotes expression of differentiated features of retinal pigmented epithelial cells: implication of laminin and basic fibroblast growth factor as active components. Exp Eye Res 1993;57:539-547.

4 Miceli MV, Newsome DA: Effects of extracellular matrix and Bruch's membrane on retinal outer segment phagocytosis by cultured human retinal pigment epithelium. Curr Eye Res 1996;15:17-26.

5 Priglinger SG, Alge CS, Neubauer AS, Kristin N, Hirneiss C, Eibl K, Kampik A, WelgeLussen U: TGF- $\beta_{2}$-induced cell surface tissue transglutaminase increases adhesion and migration of RPE cells on fibronectin through the gelatin-binding domain. Invest Ophthalmol Vis Sci 2004;45:955-963.

-6 Ioachim E, Stefaniotou M, Gorezis S, Tsanou E, Psilas K, Agnantis NJ: Immunohistochemical study of extracellular matrix components in epiretinal membranes of vitreoproliferative retinopathy and proliferative diabetic retinopathy. Eur J Ophthalmol 2005; 15:384-391.

7 Springer TA, Wang JH: The three-dimensional structure of integrins and their ligands, and conformational regulation of cell adhesion. Adv Protein Chem 2004;68:2963.
8 Hynes RO: Integrins: bidirectional, allosteric signaling machines. Cell 2002;110:673687.

-9 Ramsay AG, Marshall JF, Hart IR: Integrin trafficking and its role in cancer metastasis. Cancer Metastasis Rev 2007;26:567-578.

10 Luo BH, Springer TA: Integrin structures and conformational signaling. Curr Opin Cell Biol 2006; 18:579-586.

11 Somanath PR, Ciocea A, Byzova TV: Integrin and growth factor receptor alliance in angiogenesis. Cell Biochem Biophys 2009; 53:53-64.

12 Elner SG, Elner VM: The integrin superfamily and the eye. Invest Ophthalmol Vis Sci 1996;37:696-701.

-13 Aota S, Yamada KM: Fibronectin and cell adhesion: specificity of integrin-ligand interaction. Adv Enzymol Relat Areas Mol Biol 1995;70:1-21.

14 Yin Z, Gabriele E, Leprini A, Perris R, Colombatti A: Differential cation regulation of the $\alpha_{5} \beta_{1}$-integrin-mediated adhesion of leukemic cells to the central cell-binding domain of fibronectin. Cell Growth Differ 1997;8:1339-1347.

15 Nista A, Leonetti C, Bernardini G, Mattioni $\mathrm{M}$, Santoni A: Functional role of $\alpha_{4} \beta_{1^{-}}$and $\alpha_{5} \beta_{1}$-integrin fibronectin receptors expressed on Adriamycin-resistant MCF-7 human mammary carcinoma cells. Int J Cancer 1997;72:133-141.

16 Chon JH, Netzel R, Rock BM, Chaikof EL: $\alpha_{4} \beta_{1}$ and $\alpha_{5} \beta_{1}$ control cell migration on fibronectin by differentially regulating cell speed and motile cell phenotype. Ann Biomed Eng 1998;26:1091-1101.

17 Hakkinen L, Heino J, Koivisto L, Larjava H: Altered interaction of human granulationtissue fibroblasts with fibronectin is regulated by $\alpha_{5} \beta_{1}$-integrin. Biochim Biophys Acta 1994;1224:33-42.
18 Jin M, He S, Worpel V, Ryan SJ, Hinton DR: Promotion of adhesion and migration of RPE cells to provisional extracellular matrices by TNF- $\alpha$. Invest Ophthalmol Vis Sci 2000;41:4324-4332.

19 Davey G, Buzzai M, Assoian RK: Reduced expression of $\alpha_{5} \beta_{1}$-integrin prevents spreading-dependent cell proliferation. J Cell Sc 1999;112(pt 24):4663-4672.

20 Campochiaro PA: Pathogenic mechanisms in proliferative vitreoretinopathy. Arch Ophthalmol 1997;115:237-241.

21 Jin S, Wang Y, Jiang G: Measurements of serum and subretinal fluid before and after surgery of retinal detachment (in Chinese). Zhonghua Yan Ke Za Zhi 1997;33:36-38.

22 Hecquet C, Lefèvre G, Valtink M, Engelmann K, Mascarelli F: Activation and role of MAP kinase-dependent pathways in retinal pigment epithelial cells: ERK and RPE cell proliferation. Invest Ophthalmol Vis Sci 2002;43:3091-3098.

23 Brem RB, Robbins SG, Wilson DJ, O’Rourke LM, Mixon RN, Robertson JE, Planck SR, Rosenbaum JT: Immunolocalization of integrins in the human retina. Invest Ophthalmol Vis Sci 1994;35:3466-3474.

24 Rizzolo LJ, Zhou S, Li ZQ: The neural retina maintains integrins in the apical membrane of the RPE early in development. Invest Ophthalmol Vis Sci 1994;35:2567-2576.

25 Proulx S, Guérin SL, Salesse C: Effect of quiescence on integrin- $\alpha_{5} \beta_{1}$ expression in human retinal pigment epithelium. Mol Vis 2003;9:473-481.

-26 Robbins SG, Brem RB, Wilson DJ, O’Rourke LM, Robertson JE, Westra I, Planck SR, Rosenbaum JT: Immunolocalization of integrins in proliferative retinal membranes. Invest Ophthalmol Vis Sci 1994;35:34753485 . 
-27 Immonen I, Tervo K, Virtanen I, Laatikainen L, Tervo T: Immunohistochemical demonstration of cellular fibronectin and tenascin in human epiretinal membranes. Acta Ophthalmol (Copenh) 1991;69:466-471.

28 Goldschild M, Baudouin C: Role of integrins in ocular physiology and diseases (in French). J Fr ophtalmol 1997;20:311-325.

29 Hollborn M, Iandiev I, Seifert M, Schnurrbusch UE, Wolf S, Wiedemann P, Bringmann A, Kohen L: Expression of HB-EGF by retinal pigment epithelial cells in vitreoretinal proliferative disease. Curr Eye Res 2006; 31:863-874.
30 Carpenter G, Cohen S: Epidermal growth factor. J Biol Chem 1990;265:7709-7712.

31 Fujii K, Dousaka-Nakajima N, Imamura S: Epidermal growth factor enhancement of HSC-1 human cutaneous squamous carcinoma cell adhesion and migration on type I collagen involves selective up-regulation of $\alpha_{2} \beta_{1}$-integrin expression. Exp Cell Res 1995; 216:261-272.

32 Chen JD, Lapiere JC, Sauder DN, Peavey C, Woodley DT: Interleukin-1 $\alpha$ stimulates keratinocyte migration through an epidermal growth factor/transforming growth factor- $\alpha$-independent pathway. J Invest Dermatol 1995; 104:729-733.
33 Nagineni CN, Kutty V, Detrick B, Hooks JJ: Expression of PDGF and their receptors in human retinal pigment epithelial cells and fibroblasts: regulation by TGF- $\beta$. J Cell Physiol 2005;203:35-43.

34 Eichler W, Reiche A, Yafai Y, Lange J, Wiedemann P: Growth-related effects of oxidantinduced stress on cultured RPE and choroidal endothelial cells. Exp Eye Res 2008;87: 342-348.

35 Sastry SK, Horwitz AF: Integrin cytoplasmic domains: mediators of cytoskeletal linkages and extra- and intracellular initiated transmembrane signaling. Curr Opin Cell Biol 1993;5:819-831. 